\title{
Article \\ Continuance Intention of E-Learning: The Condition and Its Connection with Open Innovation
}

\author{
Amalia Suzianti *(D) and Sabrina Ayu Paramadini \\ Department of Industrial Engineering, Faculty of Engineering, Universitas Indonesia, Depok 16424, Indonesia; \\ sabrina.ayu81@ui.ac.id \\ * Correspondence: suzianti@ui.ac.id
}

Citation: Suzianti, A.; Paramadini, S.A. Continuance Intention of E-Learning: The Condition and Its Connection with Open Innovation. J. Open Innov. Technol. Mark. Complex. 2021, 7, 97. https://doi.org/10.3390/ joitmc7010097

Received: 26 February 2021

Accepted: 13 March 2021

Published: 16 March 2021

Publisher's Note: MDPI stays neutral with regard to jurisdictional claims in published maps and institutional affiliations.

Copyright: (c) 2021 by the authors. Licensee MDPI, Basel, Switzerland. This article is an open access article distributed under the terms and conditions of the Creative Commons Attribution (CC BY) license (https:/ / creativecommons.org/licenses/by/ $4.0 /)$.

\begin{abstract}
Recently having increased every year, in 2017, e-learning's worldwide average growth rate was $7.9 \%$ with a worldwide market of USD 52.5 billion. Holding all nations' eighth highest e-learning growth rate, Indonesia had a market of USD 12.2 billion, with a growth rate of $25 \%$ in 2017 . Obviously, Indonesia has great potential to develop a greater, even more prospective e-learning business. In fact, the Republic of Indonesia's Minister of Education and Culture plans to make e-learning permanent by changing traditional into hybrid learning, including at the primary school level. Consequently, this study recommended strategies for increasing "continuance intention" for e-learning in primary schools. A conceptual model was developed based on the Expectation-Confirmation Model of Information System Continuance and the Information System Success Model. The study's model development involved 195 teacher-respondents and used the partial least squares structural equation modeling for data analysis. Four of 11 hypotheses were rejected because they did not meet the requirements, but based on other results, 10 strategic recommendations were submitted to and assessed by several experts who used the integrated method of Importance-Performance Analysis and Kano to select four strategies selected as improvement priorities and three as keep-up-the-goodwork priorities.
\end{abstract}

Keywords: e-learning; primary education; expectation-confirmation model of information system continuance; importance-performance analysis; information system success model; kano model; PLS-SEM

\section{Introduction}

Rapid development of technology and the Internet have encouraged the education sector to use Internet-based learning media from primary to tertiary education, with the demand for e-learning increasing annually. Here, e-learning refers to an educational concept that utilizes information technology and devices to deliver learning materials and to support distance learning. Based on data from Decebo.com [1], e-learning's annual worldwide average growth rate has reached $7.9 \%$, with a market of USD 52.5 billion. In 2017, the average annual e-learning growth rates from lowest to highest were North America (4.4\%), Western Europe (5.8\%), Middle East (8.2\%), Latin America (14.6\%), Africa (15.2\%), Eastern Europe (16.9\%), and Asia (17.3\%). In the eighth highest national position, Indonesia's total e-learning market was USD 12.2 billion with average growth of $25 \%$, so the country has the potential to develop ever-greater e-learning business to meet the demand.

Currently, the increasing number of COVID-19 cases requires distance learning and encourages its rapid growth. According to the World Economic Forum [1], COVID-19 is currently preventing 1.2 billion children worldwide from attending school. According to data from katadata.co.id [2,3], more than four million teachers and 68 million students are teaching and learning at home. Therefore, the Republic of Indonesia's Ministry of Education and Culture has developed e-learning to enable teachers and students to continue educational activities. 
The key to e-learning's success, and its competitive advantage, is the high number of teachers and students who intend to continue e-learning, a concept termed "continuance intention" [4]. In Indonesia, the Minister of Education and Culture plans to establish elearning permanently, even after the COVID-19 pandemic subsides, by changing traditional learning into hybrid learning, especially since utilization of technology in education has become fundamental [5]. In Indonesia, hybrid learning can be applied even at the primary level [6], where the teacher's role is key to instructional success, reduces technological barriers, and encourages students to understand content and be active learners [6,7]. However, for primary students to follow virtual teachers is not easy; virtual teachers cannot replace "real" teachers in classrooms [8].

Given that implementing long-term e-learning in primary schools poses challenges, investigation of factors affecting its continuance intention is crucial. Therefore, this study developed a conceptual model of factors affecting continuance intention for e-learning in primary schools and recommended strategies to improve e-learning.

Several previous studies have combined Expectation Confirmation Model of Information System Continuance (ECM-ISM) and Information System Success Model (ISSM) theories to understand the continuance intention of learning $[9,10]$. The theory of ECM and ISSM itself has not been combined with the teacher self-efficacy factor.

This study confirms that there is a factor of teachers themselves to improve the use of e-learning as sustainability intentions by adding a self-efficacy factor. The role of the teacher is not only as a user, but also as an influencer that influences students to use e-learning. Therefore, the conceptual model is based on two theories, the Expectation-Confirmation Model of Information System Continuance (IS-ECM) and the Information System Success Model, with the addition of the teachers' self-efficacy factor.

\section{Literature Review}

\subsection{Expectation-Confirmation Model of IS Continuance}

With addition of the perceived usefulness variable from the Technology Acceptance Model (TAM), the IS-ECM emerges from Expectation-Confirmation Theory, and its framework consists of four variables (1) confirmation, (2) perceived usefulness, (3) satisfaction, and (4) IS continuance intention. Perceived usefulness means cognitive beliefs that influence individual intention. In fact, IS users' sustainability decisions resemble consumers' decisions to repurchase an item or service, both of which follow an initial decision and are then influenced by user experience that potentially determines reuse [11]. This model has been widely used for digital products, including sustainable e-learning $[4,9,12]$.

\subsection{Information System Success Model}

To analyze success or failure in implementing IS, DeLone and McLean [13] developed the ISSM and, after a decade, updated the model by measuring its use and success. ISSM has six factors, in this case from the teacher-user's perspective: (1) System quality to measure the effectiveness of the technology, (2) information quality to measure semantic success, (3) service quality provided by service providers to reflect service interests and support in system success, (4) intention to use, (5) user satisfaction in assessing customer satisfaction or opinion, and (6) net benefits, including balance between positive and negative impacts of using the system [14].

\subsection{Sociability Quality}

E-learning requires a further addition of the "sociability quality" factor to ISSM dimensions, as in research by Salam and Farooq [15] because, in the learning environment, social relationships (between teachers and students or between students and other students) affect the learning atmosphere and can motivate learning [12]. Sociability quality assesses the extent to which e-learning facilitates social interaction, and indeed, sociability has a strong positive effect on satisfaction and indirectly affects intention to use the system longer, that is, continuance intention. 


\subsection{Teacher Self-Efficacy}

As in the traditional classroom, in e-learning, teachers play key roles of motivating students, facilitating learning to help students understand lessons, and reducing, especially in this case, technological barriers to the teaching and learning process [16,17]. The determinant characteristic for measuring e-learning teachers' quality is teacher self-efficacy, which is the measure of teachers' ability in successful teaching and learning tasks [18]. Indeed, while user satisfaction is the most important factor in increasing continuance intention, teacher self-efficacy greatly affects satisfaction [19].

\subsection{Structural Equation Modeling (SEM)}

Structural Equation Modeling, or SEM, analyzes structural relationships commonly used in behavioral science according to two types, (1) covariance-based SEM (CB-SEM) used in confirmatory research (accept or reject) theory and (2) partial least squares SEM (PLS-SEM) used in exploratory research for developing a model [20,21]. CB-SEM is used to test theory by examining causality relationships between constructs and estimating structural model parameters that minimize the difference between estimated and sample covariances with normally distributed data that meet goodness-of-fit criteria. In contrast, PLS-SEM is used to develop a model with limited sources of the construct's theory; data do not have to be normally distributed and do not need to meet goodness-of-fit criteria.

\subsection{IPA-Kano Model Integration}

The Importance-Performance Analysis (IPA) diagram is used to prioritize attributes for improvement based on consumer evaluations of a product or service's attributes and each attribute's performance [22]. Besides that, the Kano Model categorizes a product or service's attributes based on how well it satisfies customer needs [23]. The integrated model of IPA and Kano is a new model for categorizing and diagnosing service quality attributes while also prioritizing specific strategies for attributes in each category [24]. The model measures service performance while also identifying service attributes that must be prioritized for improvement to achieve user satisfaction. The IPA-Kano integration model avoids IPA limitations of considering just one dimension of quality and also the Kano Model's boundaries that ignore performance attributes and interests.

\section{Materials and Methods}

This research was conducted systematically, from introduction to drawing conclusions and suggestions as illustrated in Figure 1.

As seen in Figure 1, this research starts with designing the conceptual framework of modified ISSM and IS-ECM model with addition of teacher self-efficacy as latent variable. From this new model, then the factors which affect the continuance intention of e-learning have been identified and analyzed in order to formulate the corresponding strategies. The strategies then were validated by experts in an in-depth interview and documented in an IPA-Kano questionnaire. Finally, the results from the IPA-Kano model resulted in several strategies which were categorized as the high prioritized strategies for the stakeholders involved in developing e-learning implementation in Indonesia. 


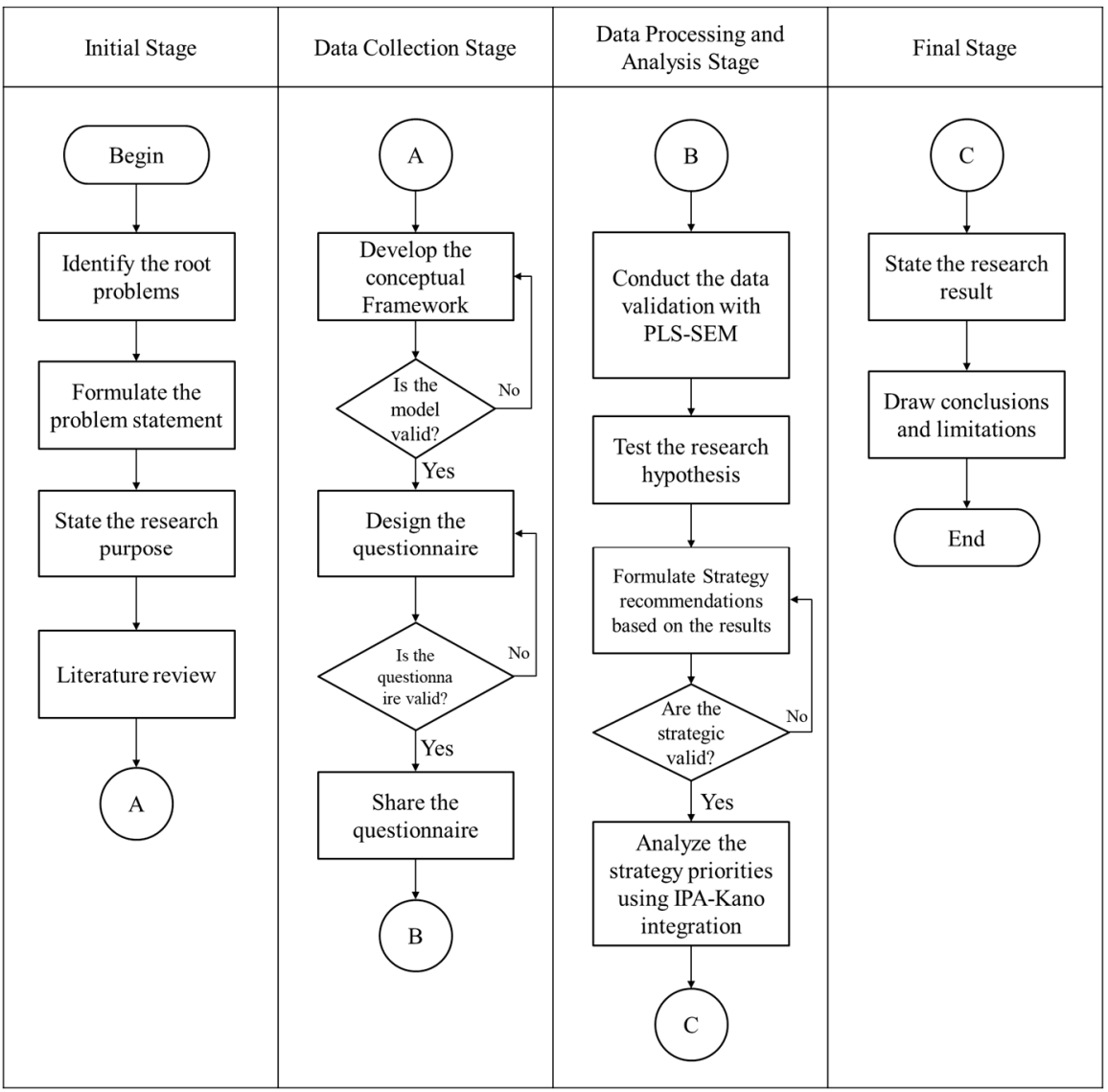

Figure 1. Research Methodology Flow Chart.

\subsection{Framework Development}

This model was originally developed as a main framework to reveal relations among factors influencing continuance intention of e-learning (Figure 2).

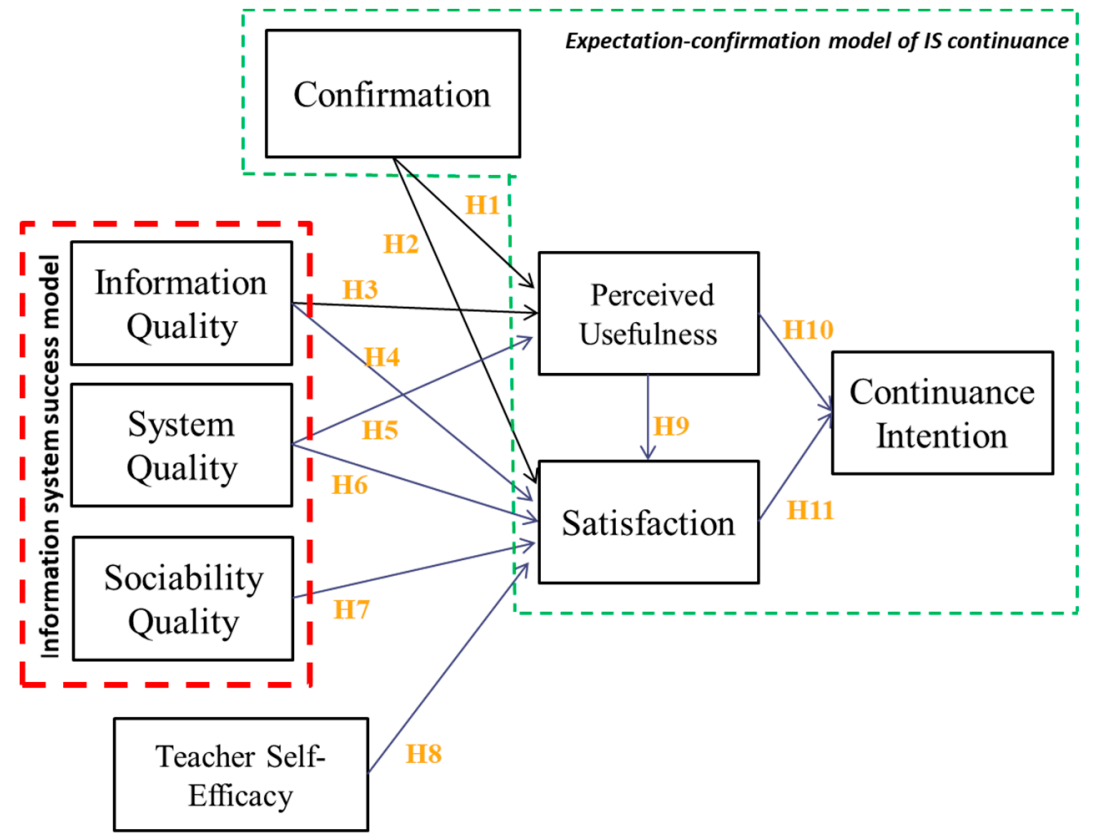

Figure 2. Conceptual Model of Continuance Intention. 
The research model has eight latent variables and 29 indicators within 11 hypotheses as seen in Table 1 and in path diagram of conceptual model in Figure 3.

Table 1. Eleven Research Hypotheses for Continuance Intention of E-learning.

\begin{tabular}{cc}
\hline Hypothesis & Description \\
H1 & Confirmation positively affects perceived usefulness. \\
H2 & Confirmation positively affects satisfaction. \\
H3 & Information quality positively affects perceived usefulness. \\
H4 & Information quality positively affects satisfaction. \\
H5 & System quality positively affects perceived usefulness. \\
H6 & System quality positively affects satisfaction. \\
H7 & Sociability quality positively affects satisfaction. \\
H8 & Teacher self-efficacy positively affects satisfaction. \\
H9 & Perceived usefulness positively affects satisfaction. \\
H10 & Perceived usefulness positively affects continuance intention. \\
H11 & Satisfaction positively affects continuance intention. \\
\hline
\end{tabular}

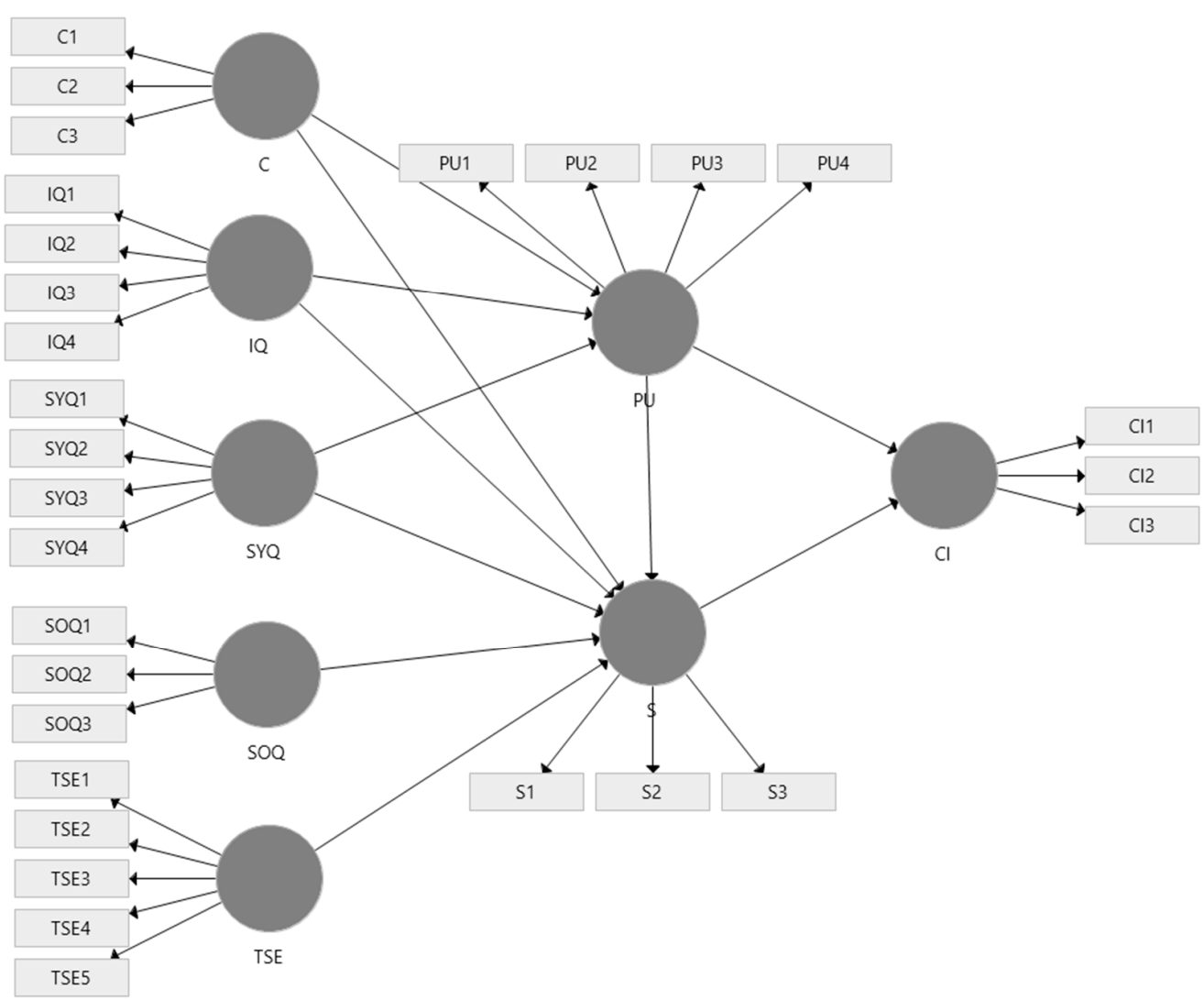

Figure 3. Path Diagram of The Conceptual Model.

By considering whether relationships between latent and indicator variables are in accord with existing conditions in Indonesia, experts in e-learning validated the conceptual model and research hypotheses. Next, a questionnaire was created and distributed online to primary teachers who had practiced e-learning. After data collection, each hypothesis was tested to determine the significance of each path's relationship.

\subsection{Sample}

For PLS-SEM, the minimum number of samples is ten times the maximum number of structural pathways directed at certain constructs in the conceptual model [25]. Therefore, this research involved a total of 195 respondents and used the Partial Least Square SEM (PLS-SEM) method for data analysis. 
Data were collected from online questionnaires distributed to primary e-learning teachers, with 30 questions considered indicator variables. The questionnaire used a 5-point Likert scale in which 1 represented "strongly disagree" and 5 represented "strongly agree". The validity test of the questionnaire was carried out by looking at the value of the KaiserMeyer-Olkin Measure of Sampling Adequacy (KMO) and Bartlett's Test of Sphericity. If the $\mathrm{KMO}$ value is greater than or equal to $0.5(\mathrm{KMO} \geq 0.5)$, the questionnaire can be considered valid. Meanwhile, the statistically significant value of Bartlett's Test of Sphericity is less than 0.05 (sig. < 0.05) [21]. Then continued with the reliability test which was conducted to see the consistency of respondents' answers to a research instrument. The reliability test was carried out by looking at the Cronbach's Alpha (CA) value, the questionnaire was considered reliable if it had a Cronbach's Alpha coefficient above 0.50 [26].

Respondents (42 males, 22\%; 153 females, $78 \%$ ) returned 195 completed questionnaires. The majority of respondents were $26-40$ years old (45\%), followed by under $25(27 \%), 41-55$ $(20 \%)$, and older than $56(8 \%)$. More than half $(55 \%)$ had practiced e-learning for under 6 months, $43 \%$ for $7-12$ months, and 1\% each for 13-18 months and longer than 18 months. The list of questions in the questionnaire is listed in Table 2.

Table 2. List of Questions.

\begin{tabular}{|c|c|}
\hline Variable & List of Questions \\
\hline Confirmation & $\begin{array}{l}\text { E-learning fulfills my need in delivering effective learning } \\
\text { E-learning supports my teaching activities more than expected } \\
\text { Overall, most of my expectations for using e-learning in education have been confirmed }\end{array}$ \\
\hline $\begin{array}{c}\text { Information } \\
\text { Quality }\end{array}$ & $\begin{array}{l}\text { E-learning provides accurate information } \\
\text { E-learning provides information in a timely manner. } \\
\text { E-learning provides me with information contained on the relevant platform/according to my } \\
\text { needs } \\
\text { E-learning provides me with information that is easy to understand }\end{array}$ \\
\hline $\begin{array}{l}\text { System } \\
\text { Quality }\end{array}$ & $\begin{array}{l}\text { E-learning allows me to control my teaching activities } \\
\text { E-learning can be used flexibly in a specific time and context } \\
\text { E-learning provides the functionality I need to conduct my teaching activities successfully } \\
\text { I have sufficient software and hardware to use e-learning }\end{array}$ \\
\hline $\begin{array}{l}\text { Sociability } \\
\text { Quality }\end{array}$ & $\begin{array}{l}\text { E-learning allows me to easily contact my students. } \\
\text { E-learning facilitates sharing of information and documents with my students } \\
\text { I can easily communicate my ideas/opinions }\end{array}$ \\
\hline $\begin{array}{c}\text { Teachers' } \\
\text { Self-Efficacy }\end{array}$ & $\begin{array}{l}\text { I believe I understand very well about the teaching material. } \\
\text { I understand the needs of each student individually. } \\
\text { I believe I can motivate students who show low interests in using e-learning } \\
\text { I believe I can respond quickly and efficiently to student needs by using e-learning } \\
\text { I can control disturbing behavior in online classes }\end{array}$ \\
\hline $\begin{array}{l}\text { Perceived } \\
\text { Usefulness }\end{array}$ & $\begin{array}{l}\text { Using e-learning improves the quality of my teaching } \\
\text { The use of e-learning increases my productivity as a teacher } \\
\text { The use of e-learning increases my effectiveness in my educational work } \\
\text { Overall, the use of e-learning is useful in my work as a teacher }\end{array}$ \\
\hline Satisfaction & $\begin{array}{l}\text { I am satisfied with my decision to use e-learning } \\
\text { I thought I was doing the right thing by deciding to use e-learning } \\
\text { I am quite happy with using the e-learning system }\end{array}$ \\
\hline $\begin{array}{l}\text { Continuance } \\
\text { Intention }\end{array}$ & $\begin{array}{l}\text { Regardless of government policies, I intend to continue and even increase the use of e-learning in } \\
\text { primary education next year } \\
\text { Regardless of government policy, I have the intention to use e-learning frequently in the future. } \\
\text { Regardless of government policy, I would advise my peers to use e-learning. }\end{array}$ \\
\hline
\end{tabular}

All questions and points on this questionnaire are validated by three experts who are directly involved in the development of e-learning, teaching actors who are involved in elementary school using e-learning. The three experts include an e-learning consultant who 
also serves as a senior e-learning product manager, the CEO of an innovation education company for elementary school children, and a teacher at one of the elementary schools. The experts also provided an assessment of strategic recommendations using the IPA-Kano integration method using 5-point Likert scale.

\section{Results}

\subsection{Model Test Results}

PLS-SEM was conducted on an initial model and the full model, with each test evaluated for the structural model and the measurement model. Prior to conducting a full-model analysis, which involved the total of 195 respondents, a pilot test with at least $30 \%$ of the total sample is necessary [21]. Therefore, this study used 59 samples in pilot study; results showed that all latent variables were reliable and valid. However, two indicators were eliminated because outer loading indicators in the pilot study were below $0.7[20,21]$. The result of final model analysis showed that all latent variables were reliable and valid.

In this study, relationships between hypotheses were revealed by relationships between the structural model's exogenous and endogenous latent variables, with a significance rate of 5\%. Every accepted hypothesis needs a t-value greater than 1.96 and a $p$-value below the significance level of 0.05 . Four of 11 hypotheses were rejected because they did not meet the requirements (Table 3).

Table 3. Hypotheses Results.

\begin{tabular}{|c|c|c|c|c|c|c|c|}
\hline & Hypotheses & $\begin{array}{l}\text { Original } \\
\text { Sample }\end{array}$ & $\begin{array}{l}\text { Sample } \\
\text { Mean }\end{array}$ & $\begin{array}{l}\text { Standard } \\
\text { Deviation }\end{array}$ & T Statistics & $p$ Values & Status \\
\hline $\mathrm{H} 1$ & $\begin{array}{c}\text { Confirmation } \rightarrow \text { Perceived } \\
\text { Usefulness }\end{array}$ & 0.118 & 0.119 & 0.071 & 1.671 & 0.095 & Rejected \\
\hline $\mathrm{H} 2$ & Confirmation $\rightarrow$ Satisfaction & 0.147 & 0.145 & 0.049 & 2.999 & 0.003 & Accepted \\
\hline $\mathrm{H} 3$ & $\begin{array}{l}\text { Information Quality } \rightarrow \\
\text { Perceived Usefulness }\end{array}$ & 0.313 & 0.310 & 0.076 & 4.096 & 0.000 & Accepted \\
\hline $\mathrm{H} 4$ & $\begin{array}{l}\text { Information Quality } \rightarrow \\
\quad \text { Satisfaction }\end{array}$ & 0.048 & 0.048 & 0.065 & 0.728 & 0.467 & Rejected \\
\hline H5 & $\begin{array}{l}\text { System Quality } \rightarrow \\
\text { Perceived Usefulness }\end{array}$ & 0.430 & 0.433 & 0.064 & 6.749 & 0.000 & Accepted \\
\hline H6 & $\begin{array}{c}\text { System Quality } \rightarrow \\
\text { Satisfaction }\end{array}$ & 0.119 & 0.116 & 0.056 & 2.109 & 0.035 & Accepted \\
\hline $\mathrm{H} 7$ & $\begin{array}{l}\text { Sociability Quality } \rightarrow \\
\text { Satisfaction }\end{array}$ & 0.064 & 0.071 & 0.058 & 1.107 & 0.269 & Rejected \\
\hline $\mathrm{H} 8$ & $\begin{array}{c}\text { Teacher Self-Efficacy } \rightarrow \\
\text { Satisfaction }\end{array}$ & 0.159 & 0.159 & 0.047 & 3.353 & 0.001 & Accepted \\
\hline H9 & $\begin{array}{l}\text { Perceived Usefulness } \rightarrow \\
\quad \text { Satisfaction }\end{array}$ & 0.487 & 0.483 & 0.063 & 7.675 & 0.000 & Accepted \\
\hline H10 & $\begin{array}{l}\text { Perceived Usefulness } \rightarrow \\
\text { Continuance Intention }\end{array}$ & 0.035 & 0.038 & 0.113 & 0.313 & 0.755 & Rejected \\
\hline H11 & $\begin{array}{c}\text { Satisfaction } \rightarrow \text { Continuance } \\
\text { Intention }\end{array}$ & 0.632 & 0.630 & 0.103 & 6.128 & 0.000 & Accepted \\
\hline
\end{tabular}

Based on $t$-value and $p$-value results, seven (i.e., $\mathrm{H} 2, \mathrm{H} 3$, $\mathrm{H} 5, \mathrm{H} 6, \mathrm{H} 8, \mathrm{H} 9$, and $\mathrm{H} 11$ ) of 11 hypotheses were accepted. The confirmation variable did not affect perceived usefulness, but this is inversely proportional to previous studies' findings $[27,28]$. However, confirmation has a positive and significant relationship to satisfaction, according to some prior research $[1,9,28]$, indicating that primary teachers' initial expectations are confirmed so that satisfaction is formed.

The study's information quality variable had a positive effect on perceived usefulness. This finding is consistent with previous studies showing that information quality affects perceived usefulness in e-learning and other fields [29-32]. Primary teachers believed that e-learning (IS) can provide rich, regularly updated information that can be adjusted to 
meet users' needs so that they perceive it as useful. However, information quality showed no effect on satisfaction, dissimilar to previous studies $[1,9,15]$.

Furthermore, service quality had positive effects on perceived usefulness, consistent with research by Cheng [29] and On et al. [33]. E-learning can provide proper system functionality to increase productivity or efficiency so that primary teachers notice e-learning's usefulness. Besides, as in previous studies, service quality positively affected satisfaction $[9,15,29]$. Primary teachers believed e-learning can provide users higher quality and functions relevant to help them conduct teaching activities, thus increasing their satisfaction and their interest in using the system.

In this case, contrary to previous studies $[7,15,34,35]$, the sociability quality variable did not affect user satisfaction positively. However, as in previous studies, teachers' selfefficacy was shown to affect satisfaction positively $[16,36]$. Obviously, teachers' role in primary schools is critical for helping and motivating the teaching and learning process.

Consistent with previous studies $[1,9,28]$, perceived usefulness was shown to significantly affect e-learning satisfaction. If the teacher considers e-learning useful, instructional quality, productivity, and satisfaction increase. However, in this study, perceived usefulness did not positively affect continuance intention.

Consistent with previous studies $[1,9,28]$, the study's last hypothesis confirmed that respondents' satisfaction positively affected e-learning's continuance intention.

\subsection{Regression Analysis}

Each measured and latent variable showed a difference in regression value, so each indicator and latent variable's importance was analyzed (Table 4), with the satisfaction variable having affected continuance intention the most $(0.632)$.

Table 4. Regression Value Comparisons among Variables.

\begin{tabular}{cccc}
\hline Measured Variable & $\begin{array}{c}\text { Measured Variable } \\
\text { Regression }\end{array}$ & Latent Variables & $\begin{array}{c}\text { Latent Variable } \\
\text { Regression }\end{array}$ \\
\hline C1 & 0.874 & Confirmation & $0.118(\mathrm{PU})$ \\
C2 & 0.914 & & $0.147(\mathrm{~S})$ \\
C3 & 0.864 & Information Quality & $0.313(\mathrm{PU})$ \\
IQ1 & 0.865 & & $0.048(\mathrm{~S})$ \\
IQ2 & 0.913 & & \\
IQ3 & 0.907 & Perceived Usefulness & $0.487(\mathrm{~S})$ \\
IQ4 & 0.827 & & $0.035(\mathrm{CI})$ \\
PU1 & 0.871 & & \\
PU2 & 0.914 & & $0.632(\mathrm{CI})$ \\
PU3 & 0.899 & Satisfaction & \\
PU4 & 0.862 & & $0.430(\mathrm{PU})$ \\
S1 & 0.919 & & $0.119(\mathrm{~S})$ \\
S2 & 0.928 & & \\
S3 & 0.912 & System Quality & \\
\hline SYQ1 & 0.808 & & \\
SYQ2 & 0.725 & & \\
SYQ3 & 0.838 & & \\
SYQ4 & 0.710 & & \\
\hline
\end{tabular}

\subsection{Strategy Recommendations Analysis}

Developed based on research hypotheses and SEM analysis, the following content lists strategic, formulated recommendations for continuance intention of e-learning:

1. Information Quality

(a) Improve quality of information, especially through accuracy and timeliness.

(b) Provide and enhance learning materials backed by main and support references. 
(c) Improve ease of understanding e-learning applications through, for instance, use of icons, symbols, illustrations, and wording easily understood by both students and teachers.

2. Quality System

(d) Provide facilities that support e-learning success, for instance, assignment collection mechanisms, assessment, and student attendance tracking.

(e) Provide tools and features for visual presentations and online discussion rooms that can support learning activities anywhere, anytime.

(f) Provide electronic devices, for instance, computers and laptops, to schools that do not have such equipment.

(g) Provide free Internet access with powerful servers to teachers and students in e-learning programs.

3. Teachers' Self-efficacy

(h) Increase teacher awareness of creating a positive learning atmosphere through, for instance, their ability to understand student needs and to motivate, pay attention to, and respect students.

(i) Organize professional development training to facilitate teachers' perception and implementation of e-learning's usefulness.

(j) Advance professional development through certification of qualified, competent e-learning teachers who, for instance, understand learning materials and are able to implement instructional design and learning.

Three experts-an e-learning consultant who also serves as a senior e-learning product manager, the CEO of an innovative education company for children, and a primary teacher-directly involved in development of e-learning and another primary teacher practicing e-learning validated these points. Based on these experts' assessment, study results demonstrated each strategy's importance and performance value in the four-quadrant IPA diagram (Figure 4).

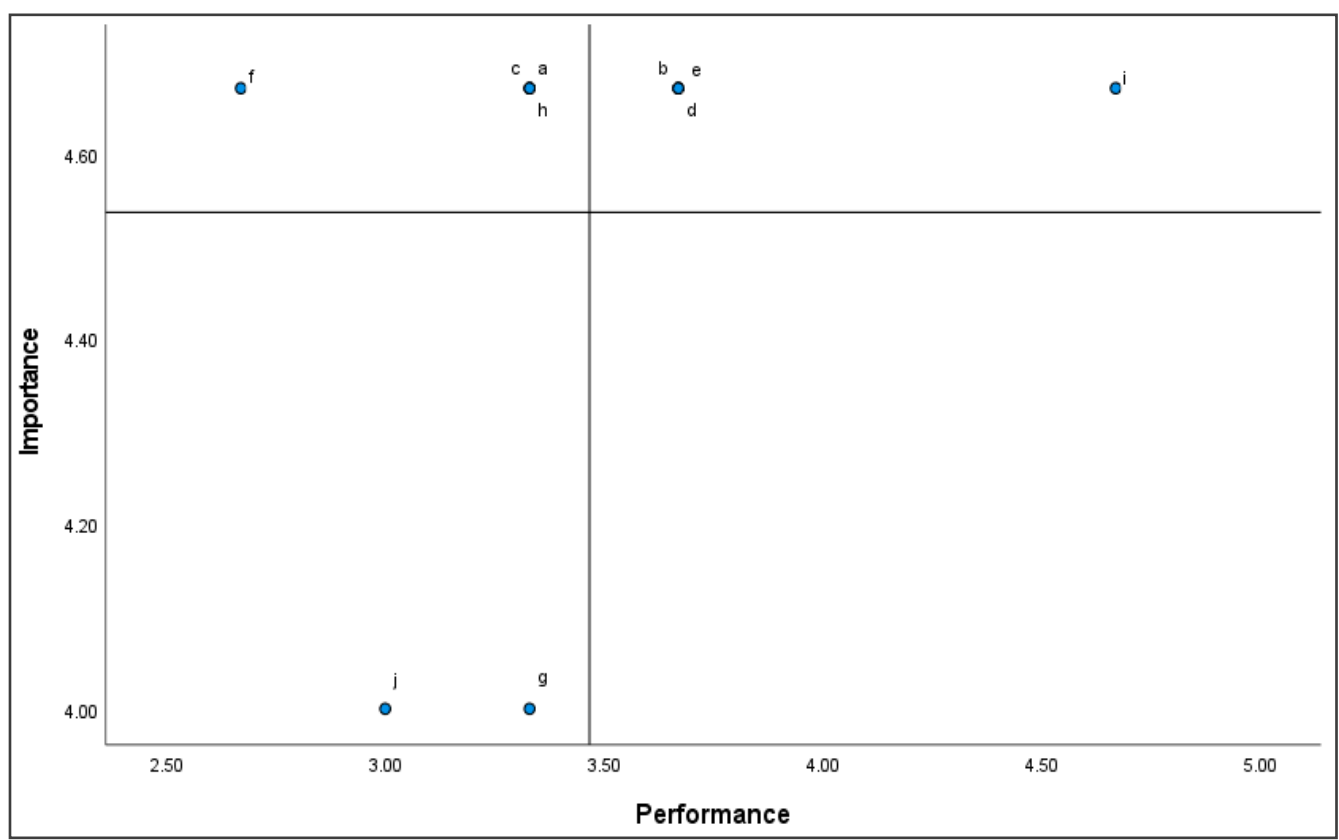

Figure 4. Importance-Performance Analysis (IPA) Graph for E-learning Strategies. 


\section{Discussion: IPA Recommendations by Quadrant, Kano Classifications, and Open Innovation}

\subsection{Strategies Based on IPA Recommendations by Quadrant}

Quadrant 1 Keep-up-the-good work: (b) Provide and enhance learning materials backed by main and support references; $(\mathrm{d})$ provide facilities that support e-learning success, for instance, assignment collection mechanisms, assessment, and student attendance tracking (e) provide tools and features for visual presentations and online discussion rooms that can support learning activities anywhere, anytime; (i) organize professional development training to facilitate teachers' perception and implementation of e-learning's usefulness.

Quadrant 2 Concentrate here: (a) Improve quality of information, especially through accuracy and timeliness; (c) improve ease of understanding e-learning applications through, for instance, use of icons, symbols, illustrations, and wording easily understood by both students and teachers; (f) provide electronic devices, for instance, computers and laptops, to schools that do not have equipment; $(h)$ increase teacher awareness of creating a positive learning atmosphere through, for instance, teachers' ability to understand student needs and to motivate, pay attention to, and respect students.

Quadrant 3 Low priority: (g) Provide free Internet access with powerful servers to teachers and students in e-learning programs; (j) further professional development through certification of qualified, competent e-learning teachers who, for instance, understand learning materials and are able to implement instructional design and learning.

Quadrant 4 Possibly overkill: None

\subsection{Kano Classifications}

Next, an analysis using the Kano method produced three Kano classifications for the strategic recommendation attributes: one-dimensional, must-be, and indifferent, with an explanation of each recommendation as follows:

One-dimensional: (a) Improve quality of information, especially through accuracy and timeliness; (b) provide and enhance learning materials backed by main and support references; (d) provide facilities that support e-learning success, for instance, assignment collection mechanisms, assessment, and student attendance tracking; (f) provide electronic devices, for instance, computers and laptops, to schools that do not have facilities. (h) Increase teacher awareness of creating a positive learning atmosphere, for instance, teachers' ability to understand student needs and to motivate, pay attention to, and respect students; (i) organize professional development training to facilitate teachers' perception and implementation of e-learning's usefulness.

Must-be: (c) Improve ease of understanding e-learning applications, for instance, through use of icons, symbols, illustrations, and wording easily understood by both students and teachers.

Indifferent: (e) Provide tools and features for visual presentations and online discussion rooms that can support learning activities anywhere, anytime; (g) provide free Internet access with powerful servers to teachers and students in e-learning programs; ( $j$ ) further professional development through certification of qualified, competent e-learning teachers who, for instance, understand learning materials and are able to implement instructional design and learning.

After IPA and Kano analysis, obtained data are classified based on the IPA-Kano integration (Table 5). As seen in Table 5, there are 4 defenseless strategy points which indicate that the strategies need to be set as improvement priority. In addition, there is 1 survival strategy and 2 major weapons strategies which are needed to be maintained. The 7 prioritized strategies for both improvement and maintenance strategies are listed and classified in Tables 6 and 7. 
Table 5. Result of Recommendation Category based on IPA-Kano Integration.

\begin{tabular}{cccc}
\hline Attributes & IPA Results & Kano Results & IPA-Kano Category \\
\hline $\mathrm{a}$ & Concentrate here & One-dimensional & Defenseless strategy point \\
$\mathrm{b}$ & Concentrate here & One-dimensional & Defenseless strategy point \\
$\mathrm{c}$ & Keep up the good work & Must-be & Survival \\
$\mathrm{d}$ & Keep up the good work & One-dimensional & Major Weapons \\
$\mathrm{e}$ & Keep up the good work & Indifferent & Elimination \\
$\mathrm{f}$ & Concentrate here & One-dimensional & Defenseless strategy point \\
$\mathrm{g}$ & Low priority & Indifferent & Elimination \\
$\mathrm{h}$ & Concentrate here & One-dimensional & Defenseless strategy point \\
$\mathrm{i}$ & Keep up the good work & One-dimensional & Major Weapons \\
$\mathrm{j}$ & Low priority & Indifferent & Elimination \\
\hline
\end{tabular}

Table 6. Prioritized Recommendations for E-learning Improvement Strategies.

\begin{tabular}{|c|c|c|}
\hline Attribute & Strategy & Improvement Priority \\
\hline a & Improve quality of information, especially through accuracy and timeliness. & 1 \\
\hline $\mathrm{b}$ & $\begin{array}{c}\text { Provide and enhance learning materials that are equipped with main references and } \\
\text { support references. }\end{array}$ & 1 \\
\hline $\mathrm{f}$ & $\begin{array}{l}\text { Provide electronic devices, for instance, computers and laptops, to schools that do } \\
\text { not have facilities. }\end{array}$ & 1 \\
\hline $\mathrm{h}$ & $\begin{array}{l}\text { Increase teacher awareness of creating a positive learning atmosphere, for instance, } \\
\text { teachers' ability to understand student needs and to motivate, pay attention to, and } \\
\text { respect students. }\end{array}$ & 1 \\
\hline
\end{tabular}

Table 7. Prioritized Recommendations for E-learning: Keep-Up-the-Good Work.

\begin{tabular}{ccc}
\hline Attribute & Strategy & Keep-Up-the-Good Work Priority \\
\hline $\mathrm{c}$ & $\begin{array}{c}\text { Improve ease of understanding e-learning applications, for instance, } \\
\text { through use of icons, symbols, illustrations, and wording easily } \\
\text { understood by both students and teachers. }\end{array}$ & 1 \\
$\mathrm{~d}$ & $\begin{array}{c}\text { Provide facilities that support e-learning success, for instance, } \\
\text { assignment collection mechanisms, assessment, and student attendance } \\
\text { tracking. }\end{array}$ & 2 \\
\hline $\mathrm{i}$ & $\begin{array}{c}\text { Organize professional development training to facilitate teachers' } \\
\text { perception and implementation of e-learning's usefulness. }\end{array}$ & 2 \\
\hline
\end{tabular}

From the IPA Kano results, there are several recommendation strategies which must be eliminated in this study, including: (e) Provide tools and features for visual presentations and online discussion rooms that can support learning activities anywhere, anytime; (f) provide electronic devices, for instance, computers and laptops, to schools that do not have facilities; (j) further professional development through certification of qualified, competent e-learning teachers who, for instance, understand learning materials and are able to design and implement e-learning.

\subsection{Continuance Intention of E-Learning and Open Innovation}

Open innovation is defined as the use of purposive inflows and outflows of knowledge to accelerate internal innovation and expand the markets for external use of innovation, respectively [37]. Thus, with the proliferation of interconnectivity and interactivity through information technology (IT), organizations now frequently engage in open innovation with its education and innovation ecosystem. Such emerging innovations can bring significant benefits to organizations [38]. Primarily, organizations can obtain complementary knowl- 
edge from collaborative partners, thereby encouraging creativity and novel solutions and resulting in the rise of new technologies or new market possibilities [39,40].

In the pandemic era, where the digital solution holds a significant role in replacing the conventional business as usual, e-learning has been proven as effective as the conventional learning process, even better from an efficiency perspective. Nevertheless, it also faces several challenges, especially in terms of continuance intention. The strategies formulated from IPA-Kano Model have shown that the quality of information systems and IT infrastructure have significant impact on e-learning continuance intention which can enable the exploration, creation, dissemination, and use of knowledge [7]. The same are also facilitated in the open innovation strategies of firms.

Collaborative innovation IT systems are used to support knowledge exchange between firms [41]. By engaging in interlinked processes that enable high-quality knowledge sharing and processing, IT-enabled absorptive capacity enhances knowledge transfer at the interorganizational level, thereby, resulting in improved knowledge recombination and creation which are also part of exploitation activities in open innovation $[35,42]$.

\section{Conclusions and Limitations}

\subsection{Conclusions}

This study focused on recommended strategies for continuance intention to use elearning in Indonesian primary schools. The conceptual model, developed through IS-ECM and ISSM theories and completed by adding sociability quality and teacher self-efficacy, includes factors of confirmation, information quality, system quality, sociability quality, teacher self-efficacy, perceived usefulness, satisfaction, and continuance intention. The data was taken during the pandemic and intends to analyse whether teachers will still need to use e-learning as part of the hybrid learning method after the pandemic. Analytical results show the conceptual model to have proven valid and reliable, with seven of 11 hypotheses accepted: H2: Confirmation positively affects satisfaction; H3: Information quality positively affects perceived usefulness; H5: System quality positively affects perceived usefulness; H6: System quality positively affects satisfaction; H8: Teacher self-efficacy positively affects satisfaction; and H11: Satisfaction positively affects continuance intention. Therefore, factors directly or indirectly influencing continuance intention for e-learning in primary schools are confirmation, information quality, system quality, teacher self-efficacy, perceived usefulness, and satisfaction. Conducted with the integrated method of IPA and Kano, the assessment indicated four strategies as improvement priorities and three as keep-up-the-good-work priorities. Furthermore, this study pointed out the important interaction effect of IT and the quality of information systems in achieving e-learning objectives which also apply to open innovation strategies. Integrating IT with other complementary organizational resources obtains a highly comprehensive understanding of its effects on e-learning and also on open innovation performance.

\subsection{Limitations}

There are some limitations in this research that should be noted. Research respondents were elementary school teachers who had already used e-learning, $91 \%$ of respondents came from Java Island. Second, research respondents were not classified based on the type of school or domicile respondent (city/district). Therefore, there are a number of gaps in our knowledge that would benefit for further research:

1. Future research can expand the number of research respondents to make it more even so that it can reflect the situation and conditions for each province and also segment research results based on demographic, behavioural, psychographic, and experience using e-learning by the respondents to deepen the results of the analysis.

2. Subsequent research can obtain expert selection from the government division authorized and expert teachers who are more experienced in e-learning exploration and traditional learning with longer experience for validation strategy recommendations. 
3. Future research can focus on specific types of e-learning so that the results can be more focused.

Author Contributions: Conceptualization, methodology, validation, writing—review and editing, supervision, project administration, funding acquisition, A.S.; software, formal analysis, investigation, resources, data curation, visualization, writing - original draft preparation, S.A.P. All authors have read and agreed to the published version of the manuscript.

Funding: This research was funded by PUTI Q1 UNIVERSITAS INDONESIA, grant number NKB1424/UN2.RST/HKP.05.00/2020.

Data Availability Statement: The data will be made available on request from the corresponding author.

Conflicts of Interest: The authors declare no conflict of interest.

\section{References}

1. Wadhwani, P.; Gankar, S. E-learning Market Trends 2020-2026 / Global Research Report. 2020. Available online: https://www. gminsights.com/industry-analysis/elearning-market-size (accessed on 6 January 2021).

2. Katadata. Empat Juta Pengajar Melakukan Pembelajaran Jarak Jauh. 2020. Available online: https://databoks.katadata.co.id/ datapublish/2020/05/05/empat-juta-pengajar-melakukan-pembelajaran-jarak-jauh\# (accessed on 6 January 2021).

3. Katadata. Pandemi Covid-19, Puluhan Juta Murid Belajar di Rumah. In Katadata.Co.Id. 2020. Available online: https: //databoks.katadata.co.id/datapublish/2020/05/05/pandemi-covid-19-puluhan-juta-siswa-belajar-di-rumah (accessed on 6 January 2021).

4. Hung, M.C.; Chang, I.C.; Hwang, H.G. Exploring academic teachers' continuance toward the web-based learning system: The role of causal attributions. Comput. Educ. 2011, 57, 1530-1543. [CrossRef]

5. Wartakota.com. Mendikbud Nadiem Makarim Permanenkan Belajar dari Rumah Meski Pandemi Covid Sudah Berakhir-Warta Kota. 2020. Available online: https://wartakota.tribunnews.com/2020/07/03/mendikbud-nadiem-makarim-permanenkanbelajar-dari-rumah-meski-pandemi-covid-sudah-berakhir (accessed on 6 January 2021).

6. Suhartono, S. Blended learning approach initiating application instructional media such as books, globes, and other. J. Kreat. 2017, 7, 177-188.

7. Petruzzellis, L.; D’Uggento, A.M.; Romanazzi, S. Student satisfaction and quality of service in Italian universities. Manag. Serv. Qual. 2006, 16, 349-364. [CrossRef]

8. Anastasiades, P.S. Distance learning in elementary schools in Cyprus: The evaluation methodology and results. Comput. Educ. 2003, 40, 17-40. [CrossRef]

9. Al-Maroof, R.S.; Salloum, S.A. An integrated model of continuous intention to use of google classroom. In Recent Advances in Intelligent Systems and Smart Applications; Hassanien, A.E., Shaalan, K., Al-Emran, M., Eds.; Springer: Berlin/Heidelberg, Germany, 2020; pp. 311-335. Available online: https://link.springer.com/chapter/10.1007/978-3-030-47411-9_18 (accessed on 6 January 2021).

10. Venter, M.; Swart, A.J. An integrated model for the continuous use intention of Microsoft Office simulation software. In Proceedings of the IEEE Global Engineering Education Conference, EDUCON, Canary Islands, Spain, 18-20 April 2018; pp. 320-329. [CrossRef]

11. Bhattacherjee, A. Understanding information systems continuance: An expectation-confirmation model. MIS Q. 2001, 25, 351-370. [CrossRef]

12. Lin, W.S.; Wang, C.H. Antecedences to continued intentions of adopting e-learning system in blended learning instruction: A contingency framework based on models of information system success and task-technology fit. Comput. Educ. 2012, 58, 88-99. [CrossRef]

13. DeLone, W.H.; McLean, E.R. Information systems success: The quest for the dependent variable. Uncertain Supply Chain Manag. 1992, 19, 9-30. [CrossRef]

14. DeLone, W.H.; McLean, E.R. The DeLone and McLean model of information systems success: A ten-year update. J. Manag. Inf. Syst. 2003, 19, 9-30. [CrossRef]

15. Salam, M.; Farooq, M.S. Does sociability quality of web-based collaborative learning information system influence students' satisfaction and system usage? Int. J. Educ. Technol. High. Educ. 2020, 17, 26. [CrossRef]

16. Fryer, L.K.; Bovee, H.N. Supporting students' motivation for e-learning: Teachers matter on and offline. Internet High. Educ. 2016, 30, 21-29. [CrossRef]

17. Parmenter, L. Achieving equity and quality in Japanese elementary schools: Balancing the roles of state, teachers, and students. Front. Educ. China 2016, 11, 272-298. [CrossRef]

18. Dellinger, A.B.; Bobbett, J.J.; Olivier, D.F.; Ellett, C.D. Measuring teachers' self-efficacy beliefs: Development and use of the TEBS-Self. Teach. Teach. Educ. 2008, 24, 751-766. [CrossRef] 
19. González, A.; Conde, Á.; Díaz, P.; García, M.; Ricoy, C. Instructors' teaching styles: Relation with competences, self-efficacy, and commitment in pre-service teachers. High. Educ. 2018, 75, 625-642. [CrossRef]

20. Chin, W.W. Issues and opinion on structural equation modeling. MIS Q. Manag. Inf. Syst. 1998, 22, vii-xvi. Available online: https:/ / www.jstor.org/stable/249674?seq=1 (accessed on 6 January 2021).

21. Hair, J.F.; Hult GT, M.; Ringle, C.M.; Sarstedt, M. A Primer on Partial Least Squares Structural Equation Modeling (PLS-SEM); Sage: Thousand Oaks, CA, USA, 2017; Volume 51.

22. Sampson, S.; Showalter, M. The Performance-Importance Response Function: Observations and Implications. Serv. Ind. J. 1999, 19, 1-25. [CrossRef]

23. Kano, N. Attractive quality and must-be quality. Hinshitsu (Qual. J. Jpn. Soc. Qual. Control) 1984, 14, 39-48.

24. Kuo, Y.F.; Chen, J.Y.; Deng, W.J. IPA-Kano model: A new tool for categorising and diagnosing service quality attributes. Total Qual. Manag. Bus. Excell. 2012, 23, 731-748. [CrossRef]

25. Barclay, D.; Higgins, C.; Thompson, R. The Partial Least Squares (PLS) Approach to Casual Modeling: Personal Computer Adoption ans Use as an Illustration. Technol. Stud. 1995, 2, 285-290.

26. Cronbach, L.J. Coefficient alpha and the internal structure of tests. Psychometrika 1951, 16, 297-334. [CrossRef]

27. Bøe, T.; Gulbrandsen, B.; Sørebø, O. How to stimulate the continued use of ICT in higher education: Integrating Information Systems Continuance Theory and agency theory. Comput. Hum. Behav. 2015, 50, 375-384. [CrossRef]

28. Chen, C.P.; Lai, H.M.; Ho, C.Y. Why do teachers continue to use teaching blogs? The roles of perceived voluntariness and habit. Comput. Educ. 2015, 82, 236-249. [CrossRef]

29. Cheng, Y.M. A hybrid model for exploring the antecedents of cloud ERP continuance: Roles of quality determinants and task-technology fit. Int. J. Web Inf. Syst. 2019, 15, 215-235. [CrossRef]

30. Cheng, Y.M. Investigating medical professionals' continuance intention of the cloud-based e-learning system: An extension of expectation-confirmation model with flow theory. J. Enterp. Inf. Manag. 2020. [CrossRef]

31. Molinillo, S.; Anaya-Sánchez, R.; Aguilar-Illescas, R.; Vallespín-Arán, M. Social media-based collaborative learning: Exploring antecedents of attitude. Internet High. Educ. 2018, 38, 18-27. [CrossRef]

32. Motaghian, H.; Hassanzadeh, A.; Moghadam, D.K. Factors affecting university instructors' adoption of web-based learning systems: Case study of Iran. Comput. Educ. 2013, 61, 158-167. [CrossRef]

33. On, N.; Ryu, G.M.; Koh, M.J.; Lee, J.R.; Kim, N.G. An empirical study on the intention to reuse computational science and engineering platforms: A case study of EDISON. Ksii Trans. Internet Inf. Syst. 2020, 14, 3437-3456. [CrossRef]

34. Hiele, T.M.; Widjaja, A.E.; Chen, J.V.; Hariguna, T. Investigating students' collaborative work to continue to use the social networking site. Int. J. Adv. Trends Comput. Sci. Eng. 2019, 8, 375-386. [CrossRef]

35. Roberts, N.; Galluch, P.S.; Dinger, M.; Grover, V. Absorptive capacity and information systems research: Review, synthesis, and directions for future research. MIS Q. 2012, 36, 625-648. [CrossRef]

36. Zain, M.Z.B.M.; Hussin, A.R.B.C. Development of instrument for assessing information systems continuance use. ACM Int. Conf. Proceeding Ser. 2019, 213-217. [CrossRef]

37. Chesbrough, W.; Vanhaverbeke, J. West, Open Innovation: Researching a New Paradigm; Oxford University Press: Oxford, UK, 2006.

38. Cui, T.; Wu, Y.; Tong, Y. Exploring ideation and implementation openness in open innovation projects: IT-enabled absorptive capacity perspective. Inf. Manag. 2018, 55, 576-587. [CrossRef]

39. Enkel, E.; Gassmann, O.; Chesbrough, H. Open R\&D and open innovation: Exploring the phenomenon. RD Manag. 2009, 39, 311-316. [CrossRef]

40. Venkatesh, V. Technology acceptance model 3 and a research agenda on interventions. Decis. Sci. 2008, 39, 273-315. [CrossRef]

41. Zammuto, R.F.; Griffith, T.L.; Majchrzak, A.; Dougherty, D.J.; Faraj, S. Information technology and the changing fabric of organization. Organiz. Sci. 2007, 18, 749-762. [CrossRef]

42. Malhotra, A.; Gosain, S.; Sawy, O.A.E. Absorptive capacity configurations in supply chains: Gearing for partner-enabled market knowledge creation. MIS Q. 2005, 7, 145-187. [CrossRef] 